\title{
A Practical English Teaching Mode of Vocational Education: Induction-Interaction Learning Community
}

\author{
Yonglong Zhang \\ School of Life Science, Southwest University \\ Chongqing 400715, China \\ E-mail: cqzhangyonglong@126.com
}

\begin{abstract}
Secondary Vocational School Students are characterized by the awkward fact "congenital malnutrition" and "acquired development deficiency", continuously adopting of the current teaching methods and modes of General Education is completely impossible. In this report, a new English Teaching Mode of Induction-Interaction Learning Community (IILC) is explored and the corresponding Teaching Evaluation System is discussed based on comparison of Teaching Mode of Lecture Method and IILC we proposed. This study shows that the Teaching Efficiency by adopting Teaching Mode of IILC is obviously improved.
\end{abstract}

Keywords: Vocational Education, Teaching Mode, Teaching Evaluation System

\section{Introduction}

With 30 years' rapid and extensive economic development, China's productivity is obviously improved and an era of rapid economic and technological change successfully completed. Improved productivity requires not only capital investment, but also a large work force that has the flexibility to acquire new skills for new jobs created by different structures of economic and occupations change. The level of competence of a country's skilled workers and technicians is a key determinant of labor force flexibility and productivity Popularization of Higher Education as well as the Elite Education has contributed greatly to the unbalanced talent structure of China, thus causing many social problems. To develop the Vocational and Technical Education is the effective solution to these problems. Vocational education, which has frequently been stigmatized as an anachronistic, dead-end path for students, is becoming increasingly important and ever negligible Vocational Education returns to investment in education.Currently, attention is paid to greatly developing Vocational Education at the strategic level. The awkward situation has come to an end. Secondary Vocational School Students, however, are characterized by the awkward fact "congenital malnutrition" and "acquired development deficiency", continuously adopting of the current teaching methods and mode of General Education is completely impossible. All of these, English teaching is the serious problem urgent to handle for their lack of interest and poor basic principles of English, which have made the English teaching difficult and complicated. Their English proficiency is significantly overestimated and the textbook is not match-able and adaptive to needs of students' physical and mental development. The real teaching aims, taking Vocational Education Center of Wushan County for example, can not complete $5 \%$ of the expected aims. What on earth they students have obtained, actually nothing after three years' English learning, is supposed to be recalled. With the rapid development of science, technology and society and the close interaction and connection of the world, the requirements of workers and technicians in knowledge and skills has largely been unregulated. Mastering of English is critical and practical, thus participating the international competitions. Cultivation of a huge work force of high-qualified and skilled is an important and urgent task in China. The problem is that Vocational Schools in response cannot complete this strategic task, of which English teaching is a bottleneck. Therefore, exploration and improvement of new teaching modes and methods should been give priority to. In this research, we proposed new teaching modes and methods. Moreover, applications and Teaching Evaluation System are discussed based on the current situation of Vocational Education Center of Wushan County in Chongqing China.

\section{Sample}

\subsection{Data collection}

The study is based on extensive survey of the students of Vocational Education Center of Wushan County, involving a number of 1500 students, covering 8 majors including Numerical Control, Cultural Tourism, Mechanical Specialty, vehicle repair, Financial Accounting, Mechanical Electronics, Garment, Hotel and Restaurant Service and Computer Science. Seven structured questions were conducted at the participants' convenience over a two-month period. Participants were free to the answers as they wished. The seven structured questions are as follows. 
1. Are you interested in English?

2. What had made you lose interest in English?

3. Do you want to learn English well if your interest is motivated?

4. What are the main obstacles of your learning English?

5. What is your real English proficiency?

6. How do you expect the teachers to teach that will make you interested in English-learning?

7. Where and when do you expect to apply English in the future and in your job?

The survey was meant to collect and reflect the true inner attitudes and problems existing in English learning of Vocational School Students, which is expected to provide some suggestions and advice in English Teaching.

After the data was collected and analyzed, we correspondingly proposed a new Teaching Mode-Induction-Interaction Learning Community. Induction-Interaction Learning Community is a system that some effective and interesting activities concerning one topic are carried on in a free and relaxed way to induce individuals' fusion into the group as a benignantly interactive learning community. The content of the lesson is major-linked, commonly perceptible. Lecture Method and mode of Induction-Interaction Learning Community were adopted to give the same lesson to 30 classes of different majors respectively. The teaching efficiency is checked by the indexes of average complete percentages of achievement of their corresponding teaching aims, degree of satisfaction and participation.

\subsection{Data analysis}

All the answers of the seven structured questions were collected and analyzed after a two month period. The statistic results display as follows (Table 1). The statistic results show that $91 \%$ of the questionnaire are not interested in English while only $9 \%$ take a slight interest.71\% of them want to learn English well.95\% of subjects regard words recitation, pronunciation and sentence translation as the main obstacles of your learning English while 5\% of them responded that they are utterly ignorant about English.67\% of the total number hold that no efforts made to learn English that lead to their losing interest in English while 33\% impart that they have no innateness for English learning because they had tried their best. Some reflect that nothing but several words was known, which makes up 47\%.Other revealed that they can read and write some simple words and get the meanings of some simple sentences. Still some other confessed they can read and write many words, sentences and get the main ideas of some passages. And the corresponding proportions are $46 \%, 7 \%$ respectively. Most of the respondents hope some interesting activities tightly linked with life, profession knowledge as well as future jobs can be carried on in class and Classroom Teaching can be carried out in a relaxed way and active atmosphere. And the proportion reached as high as $91 \%$, while the rest reported they had no ideas.73\% of them expect that they can read some materials such as newspaper, magazines, instructions and make simple conversations with foreigners. $12 \%$ of them hope they can write English poems while $10 \%$ dreamed of chatting with the foreigners freely without any difficulty.

In the survey blow (table 2.), average complete percentages of achievement (ACPA) refer to average individual complete percentages of achievement of the corresponding teaching aims in a class. For example, when the class is given by adopting Lecture Method, most of the students from all the majors could just read a few simple words. And their average percentage of achievements in their class is ACPA.

From the table, we can conclude that teaching aims of Lecture Method are over high, impractical and difficult to realize. Teaching efficiency is exceedingly poor with very low degrees of satisfaction and participation. Teaching aims of IILC is appropriate and practical to have realized. Teaching efficiency, compared with the former one, is far better with fairly high degrees of satisfaction and participation.

\section{Induction-Interaction Learning Community}

Induction-Interaction Learning Community (IILC) is an open and flexible system that some effective and interesting activities concerning one topic are carried on in a free and relaxed way to induce individuals' fusion into the group as a benignantly interactive learning community. IILC advocates compiling teaching material, formulating teaching program and constituting teaching aims autonomously according to practical situation, practical situation of different majors, needs of students' physical and mental development, the needs of social development and students' true English proficiency.

During the class, all the students feel free to move, discuss and ask questions. And there is a simple life and major-linked topic every class. They are allowed to make simple conversations and perform in groups as much as possible after demonstrations made by the teacher and their classmates. Every one can make conversations with anyone he wants. They are greatly praised by the teacher and their classmates if they engaged no matter how they performed. The teachers view all of them able and responsible and encourage them to take responsibility for their own learning and are patient enough to help them and handle any problems if they would like to reveal .Encouragement, humor and 
group-alerting statements are used to keep them interested and engaged. Induction-Interaction Learning Community values what on earth you have achieved even a few simple sentences. Teaching aims are very low, practical and clear. Moreover, Induction-Interaction Learning Community values accumulation. After three years' study, their being able to make simple conversations in familiar situations and read English newspapers, magazines and articles is fundamental task and aims of English learning. While the current Lecture Method is actually formalism phenomenon. Most of them can not write a 50-word simple composition without mistakes in simplest sentences. What they obtained is drawing hooks, doing multiple choices. Despite this, many of them failed to pass. All of these make English teaching and learning of any significance.

\section{New Teaching Evaluation System}

Teaching Evaluation System plays a guiding role in the process of students' learning. As was illustrated above, aims of English learning will never be coping with exams and doing multiple choices. Deviation of current Teaching Evaluation System leads to the malformation of the process of teaching and learning. Therefore, a scientific, reasonable and feasible Teaching Evaluation System is of great importance, which should aims at students' life-long sustainable development. Guided by the mode of Induction-Interaction Learning Community, the corresponding Teaching Evaluation System emphasize how many correct sentences you can write, how many sentences you are able to use to make conversations in different situations and how much you understand for a given passage. Teaching Evaluation System includes conversation-making in a given situation, translations, reading comprehension with essay questions and a free title composition.

\section{Conclusion}

We have discussed the proposed Induction-Interaction Learning Community and adaptive New Teaching Evaluation System as well as high integration of superiority and reality, which make it possible that IILC can be applied in teaching and learning jobs of Secondary Vocational Schools. English teaching reform of Vocational Education School should be started up to promote the reformation and innovation of teaching methods in Vocational Education. It is important to improve students' English by fowsing on students-centered teaching, creating easy and delighting English teaching environment, strengthening the practice sector, enhancing the intercommunication ability and setting up the listening-speaking-writing English patterns. Induction-Interaction Learning Community, whose kernel is to make happiness throughout English classroom, is a good practice to fit for learning characters of Vocational Education School students. Such kind of classroom proves to be vivid and vigorous, and it can fully arouse students' enthusiasm for English learning and develop their creativity, thus greatly improving the effective teaching and learning. Mode of Induction-Interaction Learning Community is expected to be experimented, expanded and popularized for its flexibility, interaction, openness, sharing and authenticity.

\section{Reference}

Anne Feryok. (2008). An Armenian English language teacher's practical theory of communicative language teaching. System, 36, 227-240.

Godius.K. \& Francis.T. (2008). The Returns to Vocational Training and Academic Education: Evidence from Tanzania. World Development.

Jonathan. M. (2007). Evidence on the returns to secondary vocational education. Economics of Education Review, 26, 559-573.

Vicki V., Dorene R. \& Alyson A. (2008). A review of research on the impact of professional learning communities on teaching practice and student learning. Teaching and Teacher Education, 24, 80-91. 
Table 1. Schematic table of investigation results of questionnaire

question number

\begin{tabular}{|c|c|c|}
\hline \multirow[t]{2}{*}{1} & yes & $91 \%$ \\
\hline & no & $9 \%$ \\
\hline \multirow[t]{2}{*}{2} & no efforts made & $67 \%$ \\
\hline & no innateness & $33 \%$ \\
\hline \multirow[t]{2}{*}{3} & yes & $71 \%$ \\
\hline & no & $29 \%$ \\
\hline \multirow[t]{4}{*}{4} & words recitation & $95 \%$ \\
\hline & pronunciation & $95 \%$ \\
\hline & translation & $95 \%$ \\
\hline & utterly ignorant & $5 \%$ \\
\hline \multirow[t]{3}{*}{5} & utterly ignorant & $47 \%$ \\
\hline & weak & $46 \%$ \\
\hline & just-so-so & $7 \%$ \\
\hline \multirow[t]{2}{*}{6} & interesting and active & $39 \%$ \\
\hline & free and relaxed & $52 \%$ \\
\hline \multirow[t]{3}{*}{7} & reading \& speaking & $73 \%$ \\
\hline & writing & $12 \%$ \\
\hline & oral speaking & $10 \%$ \\
\hline
\end{tabular}


Table 2. Schematic table of investigation results of teaching efficiency

\begin{tabular}{|c|c|c|c|c|c|}
\hline \multirow[t]{2}{*}{ major } & \multicolumn{2}{|c|}{ teaching mode } & \multirow{2}{*}{$\begin{array}{r}\text { achievement } \\
\text { (ACPA) }\end{array}$} & \multirow[t]{2}{*}{ satisfaction } & \multirow[t]{2}{*}{ participation } \\
\hline & $\mathrm{LC}$ & IILC & & & \\
\hline \multirow[t]{2}{*}{ NUMC } & - & & $5.3 \%$ & $9.8 \%$ & $8.8 \%$ \\
\hline & & - & $30.8 \%$ & $87.8 \%$ & $86.3 \%$ \\
\hline \multirow[t]{2}{*}{ CULT } & - & & $6.7 \%$ & $13.4 \%$ & $12.8 \%$ \\
\hline & & - & $66.4 \%$ & $92.9 \%$ & $91.7 \%$ \\
\hline \multirow[t]{2}{*}{$\mathrm{MECH}$} & - & & $4.1 \%$ & $6.3 \%$ & $5.8 \%$ \\
\hline & & - & $47.2 \%$ & $83.2 \%$ & $82.1 \%$ \\
\hline \multirow[t]{2}{*}{ VHRP } & - & & $2.6 \%$ & $7.1 \%$ & $6.9 \%$ \\
\hline & & - & $29.6 \%$ & $75.6 \%$ & $73.4 \%$ \\
\hline \multirow[t]{2}{*}{ FIAC } & - & & $9.5 \%$ & $14.4 \%$ & $14.1 \%$ \\
\hline & & - & $85.9 \%$ & $94.2 \%$ & $93.5 \%$ \\
\hline \multirow[t]{2}{*}{ MHET } & - & & $3.1 \%$ & $5.2 \%$ & $4.7 \%$ \\
\hline & & - & $22.7 \%$ & $97.1 \%$ & $96.2 \%$ \\
\hline \multirow[t]{2}{*}{ GADE } & - & & $5.4 \%$ & $8.4 \%$ & $8.4 \%$ \\
\hline & & - & $72.8 \%$ & $91.1 \%$ & $90.9 \%$ \\
\hline \multirow[t]{2}{*}{ HOSE } & - & & $4.9 \%$ & $8.6 \%$ & $8.1 \%$ \\
\hline & & - & $44.4 \%$ & $87.7 \%$ & $85.3 \%$ \\
\hline \multirow[t]{2}{*}{ COMS } & - & & $7.3 \%$ & $16.2 \%$ & $15.6 \%$ \\
\hline & & - & $87.6 \%$ & $97.9 \%$ & $97.7 \%$ \\
\hline
\end{tabular}

\section{Abbreviations}

IILC: Induction-Interaction Learning Community LC: Lecture Method

ACPA: average complete percentages of achievement

NUMC: Numerical Control CULT: Cultural Tourism MECH: Mechanics

MECH: Mechanics VHRP: Vehicle Repair FIAC: Financial Accounting

MHET: Mechanical Electronics GADE: Garment Design

HOSE: Hotel Service COMS: Computer Science 